\title{
GROWTH OF POTATO SHOOT CULTURES ON MEDIA WITH ANTIBIOTICS FOR ELIMINATION OF BACTERIAL CONTAMINATION
}

\author{
MARCELA GUBIŠOVÁ*, JOZEF GUBIŠ
}

\author{
National Agricultural and Food Centre - Research Institute of Plant Production, Piešt'any, \\ Slovak Republic
}

GUBIŠOVÁ, M. - GUBIŠ, J.: Growth of potato shoot cultures on media with antibiotics for elimination of bacterial contamination. Agriculture (Polnohospodárstvo), vol. 65, 2019, no. 3, pp. 99-106.

\begin{abstract}
The aim of our work was to evaluate the effect of selected antibiotics on the growth of potato shoot cultures in the Gene Bank of the Slovak Republic collection and to determine the type and dose that may be used to treat potato cultures endangered by endophytic bacteria. Antibiotics Chloramphenicol at doses 20,50 and $100 \mathrm{mg} / \mathrm{L}$, Gentamycin and Rifampicin in doses 20 , $50,100,200 \mathrm{mg} / \mathrm{L}$ and the combination of Gentamycin and Rifampicin with $100 \mathrm{mg} / \mathrm{L}$ of each were used. Growth parameters - the shoot length and the number of nodal segments per shoot and rooting of ten cultivars of Solanum tuberosum L. of different origin were evaluated. Chloramphenicol already at the lowest dose had the strong inhibitory effect on regeneration, growth, and rooting of shoots. Gentamycin inhibited the growth of shoots gradually with increasing dose of it, rooting of shoots was negatively affected using the dose $50 \mathrm{mg} / \mathrm{L}$ or higher. Rifampicin up to $100 \mathrm{mg} / \mathrm{L}$ had the minimal effect on the shoots growth, rooting of shoots was not affected, but shoots were characterised by smaller or stunted leaves. Although the growth of shoots was affected, all ten genotypes used in the experiments were able to regenerate and grow at the highest dose of Rifampicin and Gentamycin. According to the results, it is highly probable that these antibiotics up to $100 \mathrm{mg} / \mathrm{L}$ or their combination would be suitable for culture preservation of the most genotypes in the gene-bank collection. On the other hand, Chloramphenicol cannot be recommended due to its strong detrimental effect on potato shoot cultures.
\end{abstract}

Key words: potato germplasm, in vitro conservation, nodal explants, Chloramphenicol, Gentamycin, Rifampicin

Cultivated potato (Solanum tuberosum L.) is, after cereals, one of the most important crops grown in temperate and subtropical climate throughout the world. This tuberous species belongs to family Solanaceae and is mainly used for human consumption and production of starch and ethanol. Cultivated potato is an annual tetraploid plant that is multiplied and maintained vegetatively through tubers to maintain their heterozygosity (Sarkar et al. 2011). Because propagation and conservation by tubers are laborious and associated with pathogen dissemination, several in vitro techniques have been developed for propagation, virus elimination, breeding including genetic modification, conservation and exchange of potato germplasm (Morais et al. 2018). The methods are labour- and space-saving, enable to store germplasm in controlled conditions free of pathogen attack and plant material can be multiplied in a short time (Sarkar et al. 2011).

In vitro conservation is the widespread method in potatoes gene banks over the world. There are several in vitro techniques used: cryopreservation that is suitable for long-term conservation (Kaczmarczyk et al. 2011; Faltus et al. 2011) and cultivation of shoot cultures (Westcott et al. 1977; Sarkar \& Naik 1998) or microtubers induction and storage (Dobránszki

\footnotetext{
Mgr. Marcela Gubišová, PhD. (*Corresponding author), Ing. Jozef Gubiš, PhD., National Agricultural and Food Centre - Research Institute of Plant Production, Bratislavská cesta 122, 92168 Pieštany, Slovak Republic. E-mail: marcela. gubisova@nppc.sk
} 
et al. 2008) used for medium-term conservation. In the Gene Bank of the Slovak Republic, the potato germplasm is stored in the form of shoot cultures by a slow-growth method using growth retardant Daminozide (succinic acid 2,2-dimethylhydrazide). Slow-growth method enables unlimited storage of germplasm, but carries some risks including contamination of culture that can lead to its loss (Vinterhalter et al. 2008). Besides visually detectable contaminations caused by bacteria or fungi, latent infections triggered by endogenous bacteria are a serious problem in tissue cultures, because even slight changes in cultivation conditions may cause rapid proliferation of contaminants (Leifert \& Cassells 2001) posing a threat to the culture vitality and growth (Orlikowska et al. 2017).

To control both types of bacterial contamination, the use of antibiotics may be required. But, besides the inhibition of bacterial growth, antibiotics can also affect explants survival and regeneration (Morais et al. 2018). $\beta$-lactam antibiotics that inhibit cell wall synthesis (e.g. Carbenicillin, Cefotaxime, and Ticarcillin) used to have a neutral or positive impact on explant regeneration of many plants species, including potato (Mahadev et al. 2014; RákosyTican et al. 2011; Venkatasalam et al. 2013). They are most commonly used to eliminate Agrobacterium tumefaciens after genetic transformation, but have relatively weak bactericidal activities - bacterial growth was only suppressed and bacteria restarted proliferation after transfer to fresh medium without antibiotics (Ogawa \& Mii 2005).

Therefore we tried to select antibiotics from other groups: Gentamycin that belongs to aminoglycosides inhibiting protein synthesis and Rifampicin that belongs to rifampin group inhibiting RNA synthesis. They were selected according to published papers with respect to their ability to inhibit the growth of bacteria in plant tissue cultures.

Ali et al. (2018) isolated nine bacterial strains (7 of them belong to species Bacillus) from contaminated explant cultures of potato and tea and performed sensitivity test to seven antibiotics. All bacteria were sensitive to Gentamycin and Streptomycin, eight of them to a low dose of Rifampicin. Rahman et al. (2017) treated contamination of potato culture in the bioreactor with three antibiotics in different dose and they obtained the best results with
$50 \mathrm{mg} / \mathrm{L}$ of Gentamycin. Jena and Samal (2011) isolated bacterial strains from in vitro culture of another tuberous plant - sweet potato, and found out that all bacterial strains were susceptible to Gentamycin. Msogoya et al. (2012) confirmed the susceptibility of bacteria (Klebsiella spp., Erwinia spp., Proteus spp. and Staphylococcus spp.) isolated from explant culture of banana to $150-200 \mathrm{mg} / \mathrm{L}$ of Chloramphenicol, Gentamycin, and Rifampicin. Eziashi et al. (2014) also confirm the sensitivity of different bacterial species isolated from oil palm explants to Gentamycin and Rifampicin. Horáčková and Domkářová (1998) also mentioned about application of Gentamycin and Rifampicin during establishment of potato in vitro culture.

The aim of our work was to evaluate the effect of selected antibiotics on the growth of potato shoot cultures and to determine the type and dose that can be recommended for most genotypes in gene-bank collection. Growth parameters of potato shoot cultures grown on media with different concentrations or combination of these antibiotics were compared with chloramphenicol (belonging to macrolides) which had been used in our laboratory previously but used to have an adverse effect on the most of conserved genotypes. Our hypothesis was that Rifampicin or Gentamycin would not seriously inhibit the growth of shoots of potato and at least one of them may be used to treat potato in vitro cultures.

\section{MATERIAL AND METHODS}

For experiments, shoot cultures of potato genetic resources collection were used. Ten genotypes of different origin, to ensure genetic variability among them, were randomly selected: Linzer Delicates (AUT), Imperia (SWE), Sázava (CZ), Breza (SK), King Edward (GB), Lady Florina (NL), Vesna (SVN), Inovator (NL), Fanchette (FR), Lyra (DEU).

To ensure homogenity of initial material, the $3^{\text {rd }}$ and $4^{\text {th }}$ nodal segment from shoots with $6-8$ nodal segments were inoculated to testing media with or without (control variant) antibiotics. Each nodal segment was cultivated individually in a test tube $17 \times 160 \mathrm{~mm}$. Antibiotics were added to modified MS medium containing MS salts (Murashige \& Skoog $1962), 192.2 \mathrm{mg} / \mathrm{L} \mathrm{NaH}_{2} \mathrm{PO}_{4} \cdot 2 \mathrm{H}_{2} \mathrm{O}, 100 \mathrm{mg} / \mathrm{L}$ inosi- 
tol, $30 \mathrm{~g} / \mathrm{L}$ sucrose, $0.4 \mathrm{mg} / \mathrm{L}$ thiamine $\mathrm{HCl}, 2 \mathrm{mg} / \mathrm{L}$ calcium pantothenate and $8 \mathrm{~g} / \mathrm{L}$ agar. In the first experiment, the antibiotics Gentamycin, Rifampicin and Chloramphenicol in doses 20,50, and $100 \mathrm{mg} / \mathrm{L}$, and in the second experiment, $200 \mathrm{mg} / \mathrm{L}$ of Gentamycin or Rifampicin and the combination of Gentamycin and Rifampicin at $100 \mathrm{mg}$ of both were used. Tubes (40 tubes per each antibiotic variant) were cultivated under the photoperiod $16 \mathrm{~h}$ light $/ 8 \mathrm{~h}$ dark with the light intensity $70 \mu \mathrm{mol} / \mathrm{m}^{2} / \mathrm{s}$ and temperature $24 / 20^{\circ} \mathrm{C}$.

After 3 weeks of cultivation, the growth of shoots was evaluated by the number of nodal segments, shoot length and rooting frequency. Results were statistically analysed by the analysis of variance (ANOVA) and means were then separated by $L S D$ test (the least significant difference) at $\alpha=0.05$ using the statistical software STATGRAFICS Centurion XVI.II.

\section{RESULTS AND DISCUSSION}

The experiments were designed to find antibiotics useable for the cultivation of potato shoot cultures without the strong detrimental effect on their growth. In the first experiment the effect of antibiotics Gentamycin, Rifampicin and Chloramphenicol at concentrations 20,50 and $100 \mathrm{mg} / \mathrm{L}$ on shoot growth was evaluated. There were observed statistically significant differences in shoot length (Table 1a) and the number of nodal segments (Table $1 \mathrm{~b}$ ) among genotypes and antibiotic treatments at $\alpha=0.05$. Chloramphenicol already at the lowest dose had a strong inhibitory effect on regeneration of shoots in comparison with other antibiotics or control variant. Genotypes that best tolerated it were Lyra and Inovator. Rooting of shoots was also affected, only $15 \%$ of shoots rooted at the lowest dose of Chloramphenicol, and there were no rooting on the higher dose observed. Addition of Gentamycin inhibited the growth of shoots moderately compared to control variant. There were no statistically significant differences among its dose used neither for shoot length nor for the number of nodal segments. Rooting of shoots reached $80 \%$ at the lowest dose, and 5 or $2.5 \%$ at 50 and $100 \mathrm{mg} / \mathrm{L}$ respectively. In the case of Rifampicin, there was minimal effect on the shoots growth, and rooting reached 100\% like for control variant. But in terms of plant morphology, shoots grown on the medium with Rifampicin were characterized by smaller or stunted leaves (Figure 1a) in six of tested genotype, whereas on Gentamycin such effect was observed only for genotype Lady Florina.

Because the shoots were able to grow on media with Gentamycin and Rifampicin in all tested doses, in the second experiment the concentration of these antibiotics were doubled to $200 \mathrm{mg} / \mathrm{L}$ and the combination of both antibiotics with $100 \mathrm{mg} / \mathrm{L}$ of each was tested. While the average shoots length on medium with $100 \mathrm{mg} / \mathrm{L}$ of Rifampicin was not changed significantly, using $200 \mathrm{mg} / \mathrm{L}$, the shoot length was lowered 1.75-fold (Table 2a, Figure 1b). In the case of Gentamycin, both growth parameters decreased gradually. As for the number of nodal segments, all variants with Rifampicin gave in average better re-

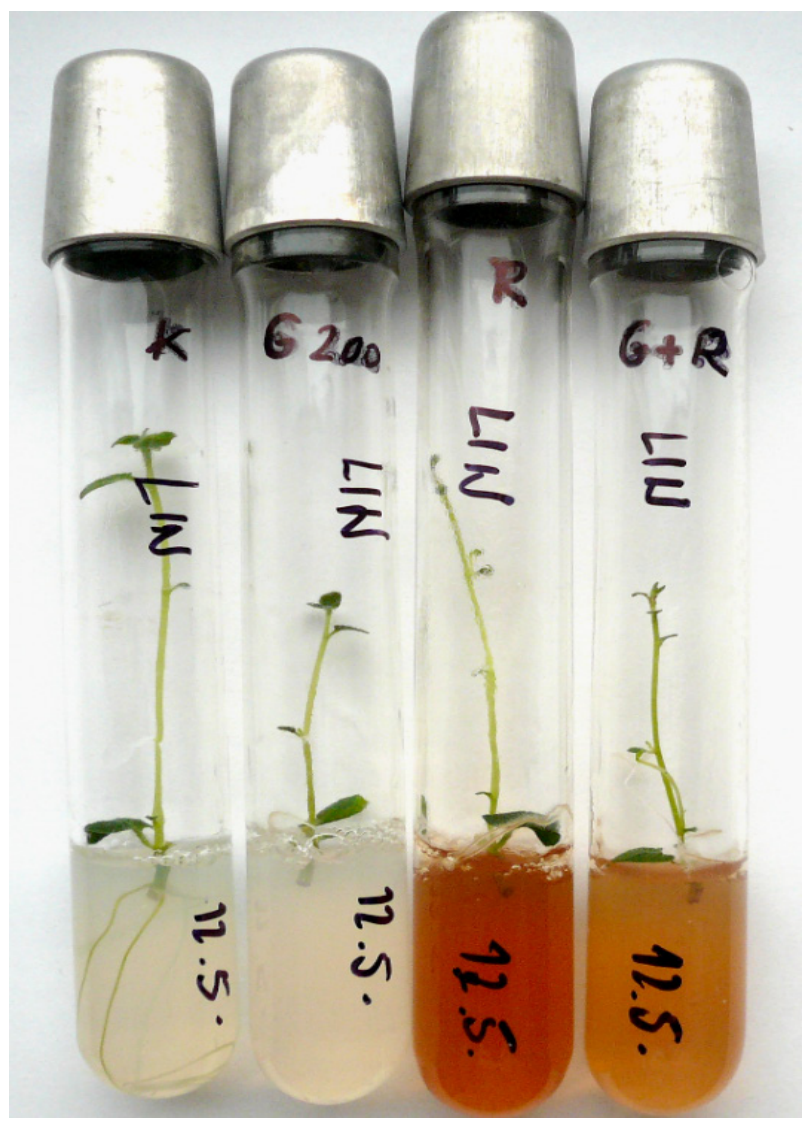

Figure 1b. Shoot culture of Solanum tuberosum, cultivar Linzer Delicates, cultivated on media with antibiotics; variants (from left): control, Gentamycin $200 \mathrm{mg} / \mathrm{L}$, Rifampicin $200 \mathrm{mg} / \mathrm{L}$ and combination of Gentamycin and Rifampicin in dose $100 \mathrm{mg} / \mathrm{L}$ of each 

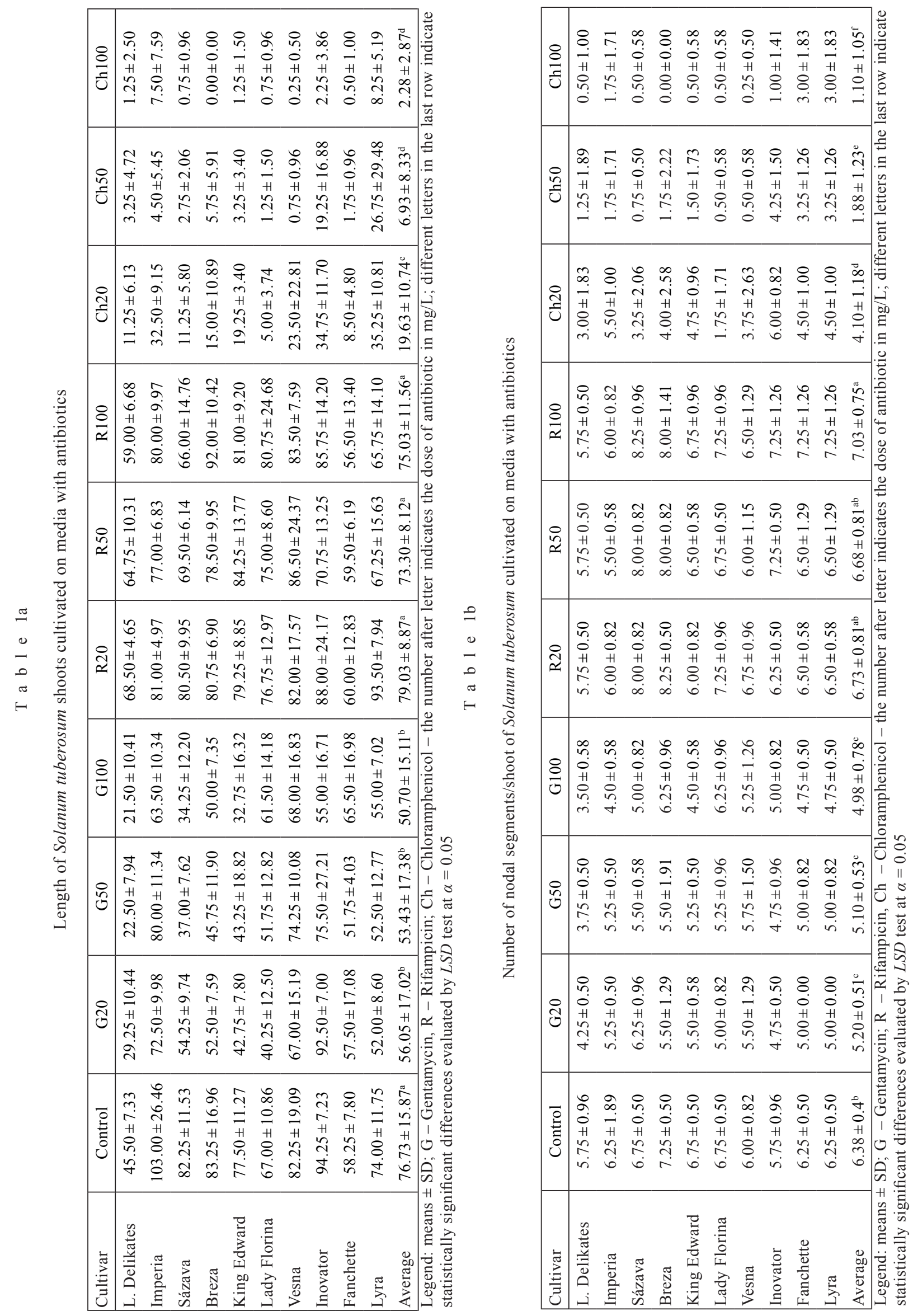
$\mathrm{T}$ a $\mathrm{b} 1$ e $2 \mathrm{a}$

Length of Solanum tuberosum shoots cultivated on media with antibiotics

\begin{tabular}{|l|c|c|c|c|}
\hline Cultivar & Control & G200 & R200 & G100+R100 \\
\hline L. Delikates & $59.50 \pm 8.43$ & $32.25 \pm 6.95$ & $48.00 \pm 8.76$ & $37.25 \pm 3.86$ \\
Imperia & $95.00 \pm 8.52$ & $58.25 \pm 10.01$ & $54.00 \pm 7.53$ & $58.25 \pm 12.28$ \\
Sázava & $80.50 \pm 23.46$ & $27.75 \pm 14.89$ & $36.50 \pm 6.19$ & $30.75 \pm 20.02$ \\
Breza & $81.80 \pm 26.29$ & $48.67 \pm 18.15$ & $38.67 \pm 5.13$ & $50.75 \pm 8.54$ \\
King Edward & $109.00 \pm 10.71$ & $48.50 \pm 15.42$ & $60.00 \pm 7.62$ & $66.50 \pm 12.29$ \\
Lady Florina & $104.25 \pm 6.95$ & $35.00 \pm 20.51$ & $46.00 \pm 5.48$ & $56.75 \pm 9.54$ \\
Vesna & $81.00 \pm 50.19$ & $29.75 \pm 15.88$ & $48.50 \pm 4.20$ & $53.75 \pm 19.19$ \\
Inovator & $96.25 \pm 4.19$ & $29.25 \pm 18.17$ & $60.75 \pm 9.43$ & $55.25 \pm 12.89$ \\
Fanchette & $78.50 \pm 13.08$ & $56.75 \pm 4.99$ & $53.50 \pm 5.00$ & $54.25 \pm 17.37$ \\
Lyra & $99.75 \pm 9.74$ & $56.00 \pm 21.80$ & $60.25 \pm 4.79$ & $46.25 \pm 7.23$ \\
Average & $88.56 \pm 14.15^{\mathrm{a}}$ & $42.22 \pm 11.93^{\mathrm{c}}$ & $50.62 \pm 8.23^{\mathrm{b}}$ & $50.98 \pm 9.92^{\mathrm{b}}$ \\
\hline
\end{tabular}

Legend: means $\pm \mathrm{SD} ; \mathrm{G}$ - Gentamycin, $\mathrm{R}$ - Rifampicin - the number after letter indicates the dose of antibiotic in $\mathrm{mg} / \mathrm{L}$; different letters in the last row indicate statistically significant differences evaluated by $L S D$ test at $\alpha=0.05$

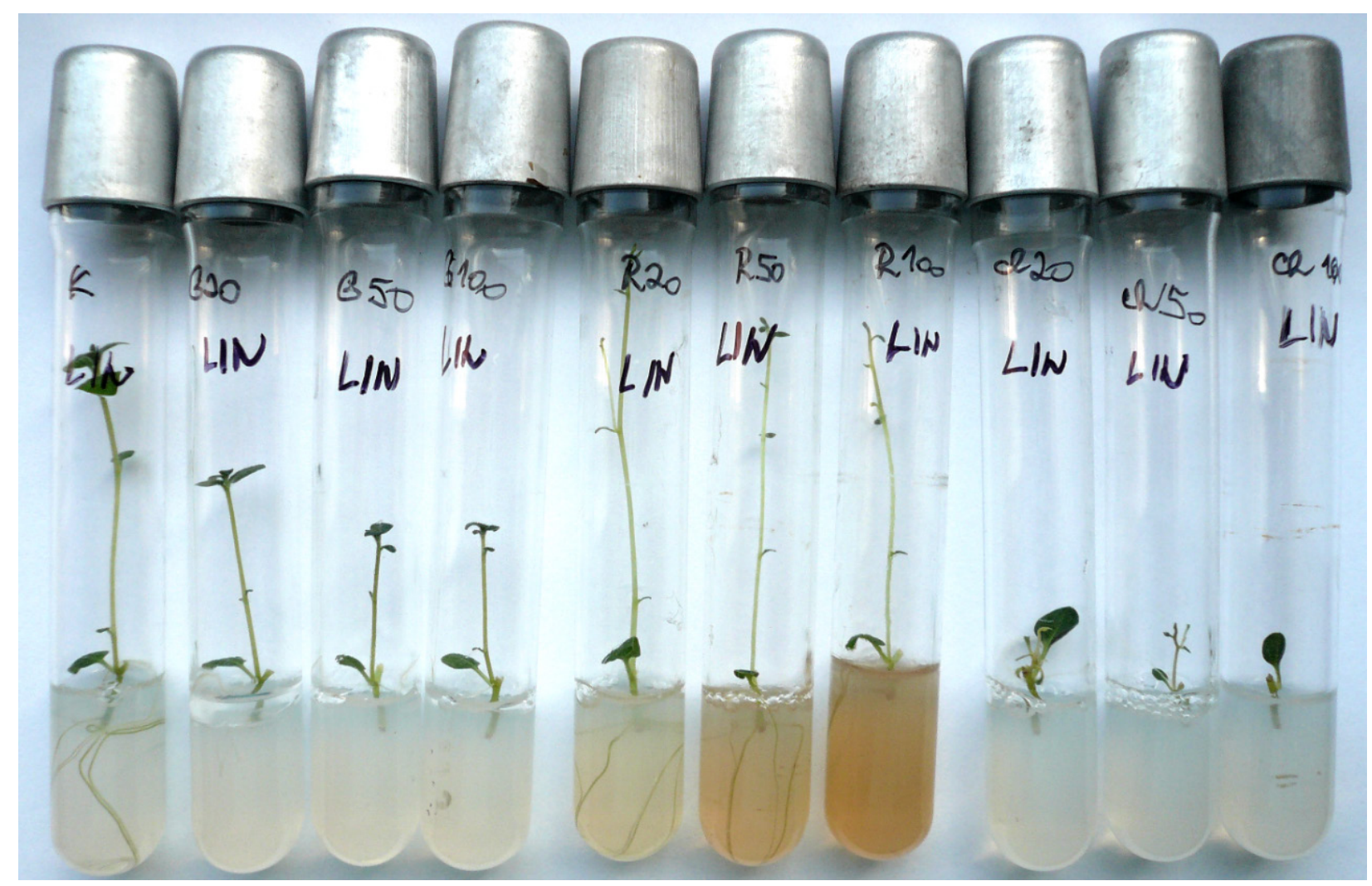

Figure 1a. Shoot culture of Solanum tuberosum, cultivar Linzer Delicates, cultivated on media with antibiotics; variants (from left): control, Gentamycin 20, 50, $100 \mathrm{mg} / \mathrm{L}$, Rifampicin 20, 50, $100 \mathrm{mg} / \mathrm{L}$ and Chloramphenicol 20, 50 and $100 \mathrm{mg} / \mathrm{L}$ 
sults than the control variant (Table $1 \mathrm{~b}, 2 \mathrm{~b}$ ). Combination of $100 \mathrm{mg} / \mathrm{L}$ Rifampicin and Gentamycin gave a similar result like $200 \mathrm{mg} / \mathrm{L}$ of Rifampicin alone for shoot length, although the number of nodal segments slightly decreased. The rooting of shoots was $95 \%$ for $200 \mathrm{mg} / \mathrm{L}$ of Rifampicin, but Genta- mycin had a negative impact on rooting also in the combination with Rifampicin.

Figure 2 summarizes both experiments where the differences among all used doses of antibiotics in both experiments relative to control variant, that is considered to be $100 \%$, are illustrated. These results

$\mathrm{T}$ a $\mathrm{b} 1$ e $2 \mathrm{~b}$

Number of nodal segments/shoot of Solanum tuberosum cultivated on media with antibiotics

\begin{tabular}{|c|c|c|c|c|}
\hline Cultivar & Control & G200 & R200 & $\mathrm{G} 100+\mathrm{R} 100$ \\
\hline L. Delikates & $6.00 \pm 0.00$ & $4.00 \pm 0.82$ & $6.00 \pm 0.82$ & $6.50 \pm 1.00$ \\
\hline Imperia & $4.75 \pm 0.50$ & $3.50 \pm 0.58$ & $5.00 \pm 0.00$ & $5.00 \pm 0.82$ \\
\hline Sázava & $6.00 \pm 0.82$ & $4.25 \pm 1.71$ & $8.00 \pm 1.41$ & $5.25 \pm 2.87$ \\
\hline Breza & $6.60 \pm 0.89$ & $4.67 \pm 1.15$ & $8.00 \pm 1.00$ & $7.00 \pm 0.82$ \\
\hline King Edward & $5.50 \pm 0.58$ & $4.75 \pm 0.96$ & $6.25 \pm 1.26$ & $6.50 \pm 1.00$ \\
\hline Lady Florina & $5.25 \pm 0.50$ & $3.25 \pm 0.50$ & $5.50 \pm 0.58$ & $6.00 \pm 0.82$ \\
\hline Vesna & $4.50 \pm 1.00$ & $3.00 \pm 0.82$ & $6.50 \pm 0.58$ & $5.75 \pm 1.26$ \\
\hline Inovator & $5.25 \pm 0.96$ & $3.50 \pm 1.29$ & $6.50 \pm 0.58$ & $5.50 \pm 1.29$ \\
\hline Fanchette & $5.75 \pm 0.96$ & $3.75 \pm 0.50$ & $6.25 \pm 0.96$ & $5.75 \pm 0.96$ \\
\hline Lyra & $6.00 \pm 0.82$ & $4.50 \pm 1.29$ & $7.50 \pm 1.00$ & $6.50 \pm 1.00$ \\
\hline Average & $5.56 \pm 0.61^{\mathrm{b}}$ & $3.92 \pm 0.58^{\mathrm{c}}$ & $6.55 \pm 0.95^{\mathrm{a}}$ & $5.98 \pm 0.61^{\mathrm{ab}}$ \\
\hline
\end{tabular}

Legend: means $\pm \mathrm{SD} ; \mathrm{G}$ - Gentamycin, $\mathrm{R}$ - Rifampicin - the number after letter indicates the dose of antibiotic in mg/L; different letters in the last row indicate statistically significant differences evaluated by $L S D$ test at $\alpha=0.05$

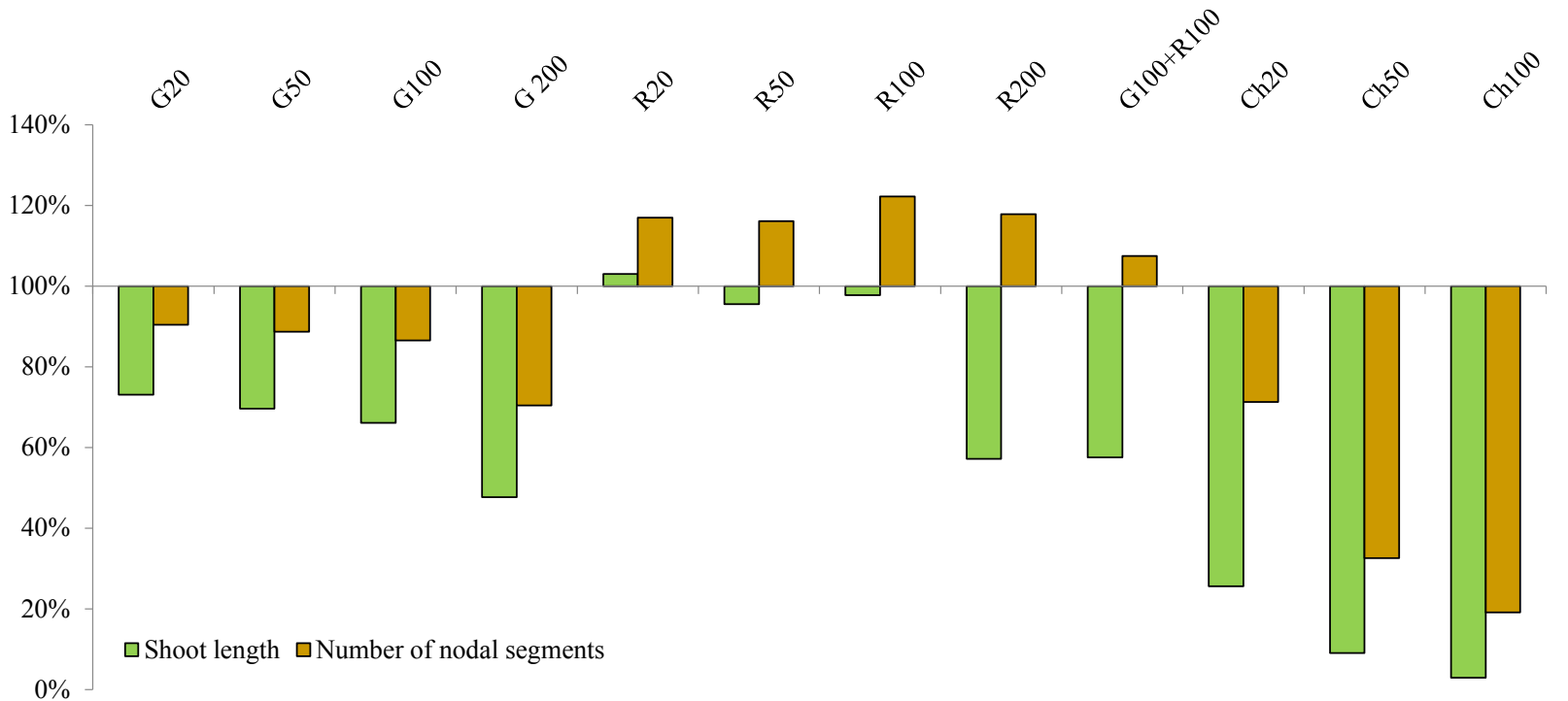

Figure 2. Growth parameters of Solanum tuberosum shoot cultures cultivated on media with antibiotics relative to control variant that is considered to be $100 \%$; $\mathrm{G}-$ Gentamycin, $\mathrm{R}-$ Rifampicin, $\mathrm{Ch}-\mathrm{Chloramphenicol}-$ the number after letter indicates the dose of antibiotic in $\mathrm{mg} / \mathrm{L}$ 
confirm the hypothesis that antibiotics Gentamycin and Rifampicin may be used for the cultivation of potato in vitro cultures in the case they are contaminated by bacteria. The use of Chloramphenicol had a detrimental effect on explant regeneration and growth and is not suitable for most of the potato genotypes.

There are only several reports concerning this problem in potato explant cultures. Rákosy-Tican et al. (2011) cultivated shoots of Solanum chacoense with Cefotaxime and confirmed the stimulating effect of this antibiotic mainly on root length and leaf fresh weight. Mahadev et al. (2014) confirmed a positive effect of Cefotaxime on the culture of Solanum viarum. Venkatasalam et al. (2013) compared the growth of three potato genotypes on $\mathrm{Ce}$ fotaxime, Carbenicillin and Streptocycline (combination of $90 \%$ streptomycin sulphate and $10 \%$ tetracycline hydroxide) and found out positive effect of Carbenicillin up to $100 \mathrm{mg} / \mathrm{L}$ and Cefotaxime up to $200 \mathrm{mg} / \mathrm{L}$ on growth parameters, and negative effect of all used concentration of Streptocycline $(100-250 \mathrm{mg} / \mathrm{L})$. On the other hand, Buckseth et al. (2017) used Streptomycin and Gentamycin and observed improvement of plantlets vigour in potato culture using 100 and $200 \mathrm{mg} / \mathrm{L}$ of Streptomycin. Gentamycin at 10 or $25 \mathrm{mg} / \mathrm{L}$ had a positive or neutral effect on growth parameters, however higher concentration had a negative impact on all four genotypes studied. Such effect of Gentamycin is in concordance with our results. To our knowledge, the effect of Rifampicin on potato shoot culture has not yet been published. Its effect on shoot growth rate was positive in our experiment, but the morphology of shoots was changed compared to Gentamycin that only slowed plantlets growth. To our observation, these changes in morphology seem to be reversible, however, this has to be checked seriously for more genotypes. Chloramphenicol had the detrimental effect in all concentration used, but for other species it may be different. For example, Amissah et al. (2016) described that $500 \mathrm{mg} / \mathrm{L}$ of Chloramphenicol had eradicated the contamination in the culture but minimally inhibited growth of plantlets of sweet potato.

Nevertheless, the tolerance of explants to antibiotics or other additives in culture media is species and genotype-dependent and needs optimization in each individual case. To summarize the results, both, Gentamycin and Rifampicin up to $100 \mathrm{mg} / \mathrm{L}$ or their combination had not toxic effect on potato plantlets. Together with Cefotaxime, the positive effect of which has been confirmed in many plant species, as well as in potatoes, these antibiotics may be used to treat bacterial contamination in potato shoot cultures. Ultimately, for each genotype of potato and mainly for each contaminating bacteria the proper antibiotic and its dose has to be determined due to the bacterial resistance or sensitivity to different antibiotics.

\section{CONCLUSIONS}

Addition of antibiotics affected shoot regeneration from nodal segments of potato. Using of Chloramphenicol had a strong inhibition effect on all tested parameters - the number of nodal segments, shoot length, and rooting of shoots. Addition of Gentamycin decreased the number of nodal segments and shoot length gradually with the increasing dose of it, rooting of shoot was negatively affected using the dose $50 \mathrm{mg} / \mathrm{L}$ or higher. Rifampicin had a minimal effect on shoot growth and rooting, the number of nodal segments was even higher compared to control. Morphology of shoots was not changed in 9 of 10 genotypes using Gentamycin, in one genotype smaller leaves were observed. But such negative effect on morphology was observed in 6 genotypes using Rifampicin. Summarizing the results, the antibiotics Rifampicin and Gentamycin in dose up to $100 \mathrm{mg} / \mathrm{L}$ or their combination can be used to treat potato shoot cultures contaminated with bacteria, but the reaction of explants may be affected by genotype. Since all 10 genotypes used in the experiments were able to grow at the highest dose of these antibiotics, it is highly probable that they would be suitable for most genotypes in the collection. The bactericidal or bacteriostatic effect of these antibiotics is, of course, dependent on the sensitivity or resistance of the bacterial species occurred in the culture to selected antibiotics.

Acknowledgements. This work was funded by the Operational Programme Research and Development co-financed from the European Regional 
Development Fund under the project ITMS 26210120039 "Systems biology for protection, reproduction and use of plant resources of Slovakia" and by the Ministry of Agriculture and Rural Development of Slovak Republic in the frame of One year topical task within the expert help „Operation of the Gene Bank of the Slovak Republic".

\section{REFERENCES}

ALI, M. - BOONERJEE, S. - ISLAM, M.N. - SAHA, M. HOQUE, M.I. - SARKER, R. 2018. Endogenous bacterial contamination of plant tissue culture materials: Identification and control strategy. In Plant Tissue Culture and Biotechnology, vol. 28, no. 1, pp. 99-108. DOI: 10.3329/ptcb. v28i1.37202

AMISSAH, S. - COLEMAN, P. - SINTIM, H. - AKROMAH, R. 2016. In vitro control of microbial contamination of sweet potatoes cultured with nodal explants. In Annual Research \& Review in Biology, vol. 9, no. 3, pp. 1-8. DOI: 10.9734/ARRB/2016/22995

BUCKSETH, T. - SINGH, R.K. - SHARMA, A.K. - SHARMA, S. - MODGIL, V. - SARASWATI, A. 2017. Effect of Streptomycin and Gentamycin on in vitro growth and cultural contaminants of potato cultivars. In International Journal of Current Microbiology Applied Sciences, vol. 6, no. 12, pp. 4038-4043. DOI: 10.20546/ijcmas.2017.612.464

DOBRÁNSZKI, J. - MAGYAR-TÁBORI, K. - HUDÁK, I. 2008. In vitro tuberization in hormone-free systems on solidified medium and dormancy of potato microtuber. In Fruit, Vegetable and Cereal Science and Biotechnology, vol. 2, special issue 1: Potato 1, pp. 82-94.

EZIASHI, E.I. -ASEMOTA, O. - OKWUAGWU, C.O. - EKE, C.R. - CHIDI, N.I. - ORUADE-DIMARO, E.A. 2014. Screening sterilizing agents and antibiotics for the elimination of bacterial contaminants from oil palm explants for plant tissue culture. In European Journal of Experimental Biology, vol. 4, no. 4, pp. 111-115.

FALTUS, M. - ZAMECNIK, J. - DOMKAROVA, J. - KREUZ, L. - HORACKOVA, V. 2011. Conservation of potato germplasm in the Czech Republic. In Acta Horticulturae, vol. 908, pp. 405-412. DOI: 10.17660/ActaHortic.2011.908.52

HORÁĆKOVÁ, V. - DOMKÁŘOVÁ, J. 1998. In vitro conservation, its utilisation in potato collection. In FABEROVÁ, I. (Ed.) - HOLUBEC, V. Metody konzervace genofondu rostlin a možnosti jejich využití v ČR: Book of proceedings. Praha : Výzkumný ústav rostlinné výroby Praha-Ruzyně, $19^{\text {th }}$ November, pp. 66-73. ISBN 80-238-3569-6

JENA, R.C. - SAMAL, K.C. 2011. Endogenous microbial contamination during in vitro culture of sweet potato [Ipomoea batatas (L.) Lam]: Identification and prevention. In Journal of Agricultural Technology, vol. 7, no. 6, pp. 1725-1731.

KACZMARCZYK, A. - ROKKA, V.M. - KELLER, E.R.J. 2011. Potato shoot tip Ccyopreservation. A review. In $\mathrm{Po}$ tato Research, vol. 54, no. 1, pp. 45-79. DOI:10.1007/ S11540-010-9169-7

LEIFERT, C. - CASSELLS, A.C. 2001. Microbial hazards in plant tissue and cell cultures. In In Vitro Cellular and Developmental Biology - Plant, vol. 37, pp. 133-138. DOI: 10.1079/IVP2000129
MAHADEV, M.D. - PANATHULA, C.S. - NAIDU, C.V. 2014. Influence of Bavistin, Cefotoxime, Kanamycin and Silver Thiosulphate on Plant Regeneration of Solanum viarum (Dunal ) - An Important Anticancer Medicinal Plant. In American Journal of Plant Sciences, vol. 5, no. 3, pp. 403-408. DOI:10.4236/ajps.2014.53053

MORAIS, T.P. - ASMAR, S.A. - JESUS SILVA, H.F. - LUZ, J.M.Q. - MELO, B. 2018. Application of tissue culture techniques in potato. In Bioscience Journal, vol. 34, no. 4, pp. 952-969. DOI: 10.14393/BJ-v34n1a2018-38775

MSOGOYA, T. - KANYAGHA, H. - MUTIGITU, J. - KULEBELWA, M. - MAMIRO, D. 2012. Identification and management of microbial contaminants of banana in vitro cultures. In Journal of Applied Biosciences, vol. 55, pp. 3987-3994.

MURASHIGE, T. - SKOOG, F. 1962. A revised medium for rapid growth and bioassays with tobacco tissue cultures. In Physiologia Plantarum, vol. 15, pp. 473-497. DOI: 10.1111/j.1399-3054.1962.tb08052.x

OGAWA, Y. - MII, M. 2005. Evaluation of 12 b-lactam antibiotics for Agrobacterium-mediated transformation through in planta antibacterial activities and phytotoxicities. In Plant Cell Reports, vol. 23, no. 10-11, pp. 736-743. DOI: 10.1007/s00299-004-0885-9

ORLIKOWSKA, T. - NOWAK, K. - REED, B. 2017. Bacteria in the plant tissue culture environment. In Plant Cell Tissue and Organ Culture, vol. 128, no. 3, pp. 487-508. DOI: 10.1007/s11240-016-1144-9

RAHMAN, Z. - SHAHINUL ISLAM, S.M. - CHOWDHURY, A.N. - SUBRAMANIAM, S. 2017. Identification and prevention of microbial contaminants of potato culture in temporary immersion bioreactor (TIB) system. In Malaysian Journal of Microbiology, vol. 13, no. 4, pp. 289-297.

RÁKOSY-TICAN, E. - AURORI, C. - AURORI, A. 2011. The effects of cefotaxime and silver thiosulphate on in vitro culture of Solanum chacoense. In Romanian Biotechnological Letters, vol. 16, no. 4, pp. 6369-6377.

SARKAR, D. - NAIK, P.S. 1998. Factors affecting minimal growth conservation of potato microplants in vitro. In Euphytica, vol. 102, no. 2, pp. 275-280. DOI: 10.1023/A:1018309300121

SARKAR, D. - PANDEY, K. - SHARMA, S. - CHANDEL, P. 2011. Potato. In SINGH, H.P. (Ed.) - PARTHASARATHY, V.A. - NIRMAL BABU, K. Advances in horticultural biotechnology. Regeneration systems, vol II: vegetables, ornamentals and tuber crops. New Delphi : Westville Publishing House, pp. 319-354. ISBN 978-81-85873-66-4

VENKATASALAM, E.P. - PANDEY, K.K. - SINGH, B.P. VANDANA, T. - SHARMA, S. - SOOD, R. - SHARMA, A.K. 2013. Efficacy of antimicrobial agents on in vitro micropropagation potential of potato. In Potato Journal, vol. 40, no. 1, pp. $45-54$.

VINTERHALTER, D. - DRAGIĆEVIĆ, I. - VINTERHALTER, B. 2008. Potato in vitro culture techniques and biotechnology. In Fruit, Vegetable and Cereal Science and Biotechnology, vol. 2, special issue 1: Potato 1, pp. 16-45.

WESTCOTT, R.J. - HENSHAW, G.G. - ROCA, W.M. 1977. Tissue culture storage of potato germplasm: Culture initiation and plant regeneration. In Plant Science Letters, vol. 9 , no. 4 , pp. $309-315$. DOI: 10.1016/0304-4211(77)90101-8

Received: February 25, 2019 Accepted: September 12, 2019 